\title{
MOTIVATIVE STIMULATION AS A COMPONENT OF MANAGEMENT IN ENTREPRENEURSHIP
}

\author{
Maryna Ponomarova ${ }^{1}$ \\ Evgenia Krivosheya ${ }^{2}$ \\ Andrey Artemenko ${ }^{3}$
}

DOI: https://doi.org/10.30525/978-9934-588-38-9-33

\begin{abstract}
The article covers the issues of motivational management and its impact on the development of entrepreneurial activity. The analysis of the dynamics of favorable conditions of conducting business in Ukraine, as a key characteristic of the level of business development. The existence of interconnection between intellectual capital and the level of development of entrepreneurial activity is substantiated.

The article investigates the economic substance of motivation entrepreneurship. The research determined the role of motivation in the activation of entrepreneurship. The article pointed out that motivation is an essential part of business. Motivation is a process that is aimed at encouraging businesses to efficient economic activity, which results in the achievement of the specific economic goals. In general, all business activities related to the satisfaction of social needs. Businessman takes on property risks of economic activity from different motives. The main motivation of business is business profit. Features an internal nature of income from business consists in the fact that heobtained through market exchange made entrepreneur products or services carried out and the result is a betteruse of economic resources of the entrepreneur in the process of economic exchange.Their essence is disclosed and the justification of expediency of introduction by business entities is provided. Recom-
\end{abstract}

\footnotetext{
${ }^{1}$ Ph.D. in Economics, Associate Professor, Associate Professor of the Department of Marketing, Entrepreneurship and Production Organization,

Kharkiv National Agrarian University named after V.V. Dokuchaiev, Ukraine

ORCID: https://orcid.org/0000-0001-8463-821X

${ }^{2}$ Postgraduate Student of the Department of Marketing,

Entrepreneurship and Production Organization,

Kharkiv National Agrarian University named after V.V. Dokuchaiev, Ukraine

${ }^{3}$ Postgraduate Student of the Department of Marketing,

Entrepreneurship and Production Organization,

Kharkiv National Agrarian University named after V.V. Dokuchaiev, Ukraine

(C) Maryna Ponomarova, Evgenia Krivosheya, Andrey Artemenko
} 
mendations on the implementation of an effective system of motivation in entrepreneurial activity are developed on the basis of improving the existing system of remuneration, which aims to increase the intellectual potential of employees and the implementation of organizational and moral-psychological methods of motivation. Scientific novelty of the obtained results is the further development of theoretical and methodological support of motivational management in entrepreneurial activity. Further development of methodological recommendations on the introduction of motivational management in entrepreneurial activity has been developed. Further development of methodical recommendations on the introduction of motivational management in entrepreneurial activity. These recommendations include the introduction of an effective system of motivation in entrepreneurial activity, which is precisely the practical value of the article.The paper summarizes, the motivation in entrepreneurship should be considered as an economic process that may regulate to achieve the desired positive economic effect on economic activity entrepreneur. Motivation - aspecific set of tools to stimulate and coercion that can influence the cost-effectiveness as part of doing business.

\section{Introduction}

The active development of entrepreneurship is a prerequisite for ensuring sustainable economic development in a market economy. This is the main basis for the formation of effective competitive environment, improving the quality of life and promoting scientific and technological progress. Motivation of entrepreneurial activity is one of the types of motivation of work. and targeted economic instruments, levers and factors, as well as methods and forms of encouraging people to work, as well as the coordination of other interests of economic subjects.

However, the overall methodology and system of levers and tools to enhance business activity is not holistic and does not improve the competitiveness of domestic business entities. Thus, it is necessary to find effective mechanisms for influencing the motivation of entrepreneurs in the economic activity, which will provide not only economic development as such, but also the development of the person as a person capable of entrepreneurial activity and having a material basis for its realization. Also required is a state strategymotivation, which would ensureactivation of medium and small enterprises, as well as other entitiesentrepreneurial activity. 


\section{Current status of management of entrepreneurship}

Entrepreneurship is one of the main components that ensures the socio-economic growth of the country. It is responsible for solving such important economic and social tasks as saturation of the national market with various goods, solving the problem of employment of the population, development of competition, formation of economic culture, etc. [1, p. 11].

An important prerequisite for the development of modern society in the conditions of maximum use of innovations and innovations is the special attention of staff, which creates the preconditions for economic growth and competitiveness of both the individual worker and the enterprise as a whole, and also guarantees its economic security. In addition to certain conditions of employment, each employee has his or her own personal motives and incentives, which encourage the daily fulfillment of the tasks set before him. Therefore, employee behavior analysis requires the application of knowledge in combination with experience, professional skills, educational attainment, psychological and material status, etc.

However, as the experience of highly developed countries in the world shows, none of the tasks of managing and implementing innovative activities in any field of activity can be accomplished without the interest of employees in its solution. This is because finding effective methods of motivation and stimulation

Today, the development of entrepreneurship is one of the most important factors in the socio-economic growth of the country. Effective development of entrepreneurship forms a competitive environment for business entities of different types of economic activity for development of which are favorable conditions and resource potential, interest of foreign and domestic investors. At the same time, successful business activity solves a number of important tasks, in particular, contributes to the replenishment of budgets of different levels, the saturation of the consumer market with goods and services, creating new jobs, increasing employment and reducing unemployment.

In order to analyze Ukraine's place in the international business environment and find out how easy it is for Ukrainian businesses to do business, it is advisable to consider the rating of DoingBusiness - a study conducted by the World Bank, assess the regulatory climate in the country, or how any legislative changes are implemented to improvement of business activ- 
ity. This rating covers 190 countries, within the framework of the study an assessment was made of 10 components characterizing the conditions: business registration; obtaining a building permit; connection to energy supply systems; property registration; obtaining a loan; protection of investors' rights; taxation; international trade; enforcement of contracts; the solution of insolvency problems [2].

Each indicator has an equal weight. However, variables such as macroeconomic policy, infrastructure quality, workforce skills, exchange rate fluctuations, investor sentiment, security, and corruption are not taken into account. Thus, the conditions of organization and doing business are considered without political considerations, only at the level of state regulation. In the final rating, all countries are ranked in terms of favorable business conditions, where a high country position means that its regulatory climate facilitates business. The resultant level is the national average of 10 indicators (Table 1).

Table 1

Ukraine's position in the DoingBusiness rating in 2016-2018

\begin{tabular}{|c|c|c|c|c|}
\hline \multirow{2}{*}{ Indicator } & \multicolumn{3}{|c|}{ Place of Ukraine } & Changes \\
\cline { 2 - 5 } & $\mathbf{2 0 1 6}$ & $\mathbf{2 0 1 7}$ & $\mathbf{2 0 1 8}$ & $\mathbf{2 0 1 7 + / - 2 0 1 8}$ \\
\hline Registration of enterprises & 20 & 52 & 56 & -4 \\
\hline Obtaining building permits & 140 & 35 & 30 & +5 \\
\hline Property registration & 63 & 64 & 63 & +1 \\
\hline Lending & 20 & 29 & 32 & -3 \\
\hline Investor protection & 70 & 81 & 72 & +9 \\
\hline Taxation & 84 & 43 & 54 & -11 \\
\hline International Trade & 115 & 119 & 78 & +41 \\
\hline Ensuring the execution of contracts & 81 & 82 & 57 & +25 \\
\hline Restoration of solvency & 150 & 149 & 145 & +4 \\
\hline Overall rating & $\mathbf{8 0}$ & $\mathbf{7 6}$ & $\mathbf{7 1}$ & $+\mathbf{5}$ \\
\hline
\end{tabular}

Analyzing Ukraine's place in the DoingBusiness rating, we see an overall rating increase of 5 positions (from 76 places to 71), the country showed an increase by six indicators, most by the component «international trade» +41 positions (from 119 to 78 ) and «ensuring compliance contracts " +25 (from 82 to 57 ). There was also an increase of 9 positions in the direction of «investor protection», 5 - «obtaining building permits», 4 «settlement of insolvency», 1 - «registration of property». 
There was no improvement in Ukraine's position on the criteria of «taxation» -11 , «connection to the grid» -7 , «registration of enterprises» -4 , «lending» -3 .

Over the last year, Ukraine has significantly improved its business climate, but its overall position in the Rating has also been affected by significant changes in other countries, as many of them are DoingBusiness-oriented in their internal activities. Thus, according to the World Bank statistics, 3500 reforms have been implemented for the 16 years of existence of this rating, from 02.06.2017 to 01.05.2018 128 countries have implemented a record 314 reforms that improve regulation in all areas that measure for the "DoingBusiness" rating.

In 2018, New Zealand ranked second in terms of business-friendly conditions, which placed Singapore second, followed by Denmark. For the first time, the top ten countries also included: South Korea, Hong Kong, Norway, the United Kingdom, the United States of America, Sweden and Macedonia. The most unfavorable countries for doing business in 2018 are recognized by South Sudan, Venezuela, Libya, Eritrea and Somalia.

The closest neighbors to the rating for Ukraine were: Tunisia, ranking 68th, China -69 , San Marino - 70, and lower on the list of Bosnia and Herzegovina - 72, Vietnam - 73, Qatar - 74. Geographically neighboring countries occupy a lot of us. higher positions. Georgia is ranked 16th, Kazakhstan - 35, Belarus - 37, Armenia - 38, Russia - 40, Moldova - 44, Romania - 36. Therefore, Ukraine needs to be more determined to implement deregulation reforms, as our country is far inferior to neighboring countries, whose rating is almost twice as high.

According to World Bank estimates, raising the country to one position brings the States an annual inflow of foreign direct investment of \$250-500 million.

To analyze the current economic situation and activity of Ukrainian enterprises, it is necessary to refer to the statistical compilation of the State Statistics Service of Ukraine [3]. Let's look at the dynamics of the number of economic entities in 2016-2018 in four areas of doing business in Ukraine. Entrepreneurship includes small, medium, large and micro enterprises. According to the Economic Code of Ukraine (as of February 3, 2019) individuals-entrepreneurs cannot be subjects of big business (Table 2). 
Maryna Ponomarova, Evgenia Krivosheya, Andrey Artemenko

Table 2

Dynamics of the number of enterprises in Ukraine 2016-2018, mln

\begin{tabular}{|c|c|c|c|c|c|}
\hline & \multirow{2}{*}{2016} & \multirow{2}{*}{2017} & \multirow{2}{*}{2018} & \multicolumn{2}{|c|}{$2018-2016$} \\
\hline & & & & units & $\%$ \\
\hline \multicolumn{6}{|c|}{ The entities of a large enterprise } \\
\hline Large enterprises & 423 & 383 & 399 & -30 & 94,3 \\
\hline Individual entrepreneurs & - & 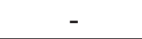 & - & - & - \\
\hline \multicolumn{6}{|c|}{ The subjects of medium-sized entrepreneurship } \\
\hline Large enterprises & 15230 & 14832 & 14937 & -293 & 98,0 \\
\hline Individual entrepreneurs & 307 & 281 & 317 & 10 & 103,3 \\
\hline \multicolumn{6}{|c|}{ The subjects of small entrepreneurship } \\
\hline Large enterprises & 327814 & 291154 & 322920 & -4894 & 98,5 \\
\hline Individual entrepreneurs & 1630571 & 1558880 & 1466486 & -164085 & 89,9 \\
\hline \multicolumn{6}{|c|}{ Subjects of micro entrepreneurship } \\
\hline Large enterprises & 284241 & 247695 & 278102 & -6139 & 97,8 \\
\hline Individual entrepreneurs & 1626589 & 1553041 & 1458980 & -167609 & 89,7 \\
\hline
\end{tabular}

Analyzing the dynamics of changes in the number of enterprises in Ukraine, we observe a tendency to decrease, which is caused by unfavorable socio-economic conditions, so the entities of large enterprises decreased by 30 units, in turn, in the medium-sized enterprises of medium enterprises decreased by $2 \%$ (293 units) and natural persons entrepreneurs increased by 3.3\% (10 units), but this change is caused by the decrease in the number of large and medium-sized enterprises. Small and micro enterprises decreased by 4894 and 6139 units respectively, by $10 \%$ less by individual entrepreneurs in these two categories. This situation clearly illustrates that it is becoming increasingly difficult to run a small business in Ukraine; changes in the Tax Code of Ukraine became the main reason for this, namely, raising the minimum wage to $3200 \mathrm{UAH}$. Starting from this, the amount of the Single Social Security Contribution to the Pension Fund will be equal to $22 \%$ of the minimum wage, ie UAH 704. month. Even for those who do not show self-employment income, it is now compulsory to pay a single tax and social contribution. The result was a significant increase in loss-making enterprises, and consequently a reduction in the number of enterprises.

In order to investigate how effective the existing business entities are, it is advisable to examine the volume of products sold (Table 3), because the high rates are evidence of high-efficiency enterprise development, as it shows the volume of goods that are received and ready for consumption. 


\section{The volume of sold products (goods, services) in Ukraine for 2016-2018, million UAH}

\begin{tabular}{|l|c|c|c|c|c|}
\hline & $\mathbf{2 0 1 6}$ & $\mathbf{2 0 1 7}$ & $\mathbf{2 0 1 8}$ & $\mathbf{2 0 1 8}-\mathbf{2 0 1 6}$ \\
\cline { 5 - 7 } & 2053189,5 & 2391454,3 & 2929516,6 & 876327,1 & 142,7 \\
\hline $\begin{array}{l}\text { The entities of a large } \\
\text { enterprise }\end{array}$ & 2184376,8 & 2683303,5 & 3314956,1 & 1130579,3 & 151,8 \\
\hline $\begin{array}{l}\text { The subjects of medium- } \\
\text { sized entrepreneurship }\end{array}$ & 21318974,1 & 1651982,0 & 2067799,2 & 748825,1 & 156,8 \\
\hline $\begin{array}{l}\text { The subjects of small } \\
\text { entrepreneurship }\end{array}$ & 1318 . & & & & \\
\hline $\begin{array}{l}\text { Subjects of micro } \\
\text { entrepreneurship }\end{array}$ & 665725,8 & 811546,4 & 1052149,5 & 386423,7 & 158,0 \\
\hline
\end{tabular}

From the data of Table 3, we observe that despite the significant reduction of enterprises in Ukraine over the period 2016-2017, sales volumes have increased significantly, especially for small and micro enterprises by $56.8 \%$ and $58.0 \%$ respectively. Sales of products by large and medium-sized enterprises have also increased by almost 1.5 times. These changes are dictated primarily by a significant increase in the price of products, but the effective management system, competent organization of work and the use of scientific and technological progress have a positive effect.

Given the significant dissonance between the reduction of enterprises and the increase in sales, it is advisable to determine the trend of profitability of Ukrainian enterprises. In 2018 compared to 2016, corporate profits increased from UAH 352,980.4 million to 515460.6 , ie by $46 \%$, losses on the contrary have a downward dynamics, so in recent years the loss decreased from UAH 726496.4 million to 346707.8 , ie, there is a tendency to reduce unprofitable enterprises, they improve their financial results, and it is desirable to consolidate this trend.

In general, over the last three years, $73 \%$ of all Ukrainian enterprises have been making a profit and only $27 \%$ have been making losses. Despite such positive results, the number of enterprises in Ukraine is constantly declining, it is difficult to start one's own business, and it is difficult to start an existing one.

Tracking the state of entrepreneurship in Ukraine, it is noticeable that the state is engaged in regulating the business sector policy, a positive 
consequence of which is the improvement of permitted registrations of property rights, simplified procedures for opening and closing businesses, providing administrative services, reducing tax pressure, developing infrastructure for providing business. Small business information, material, financial and personnel support, so on the one hand, at the legislative level, conditions are created for ease DoingBusiness, a 71st place out of 190 in the DoingBusiness rating, has significantly increased the level of profitability of enterprises, but on the other hand, the practical implementation of these conditions requires change and control. Entrepreneurs work under difficult socio-economic conditions, so the depreciation of the currency, constant changes in economic conditions with the European Union, reform of decentralization, reduction of distribution channels have led to a significant decrease in the number of enterprises, which negatively reflects on the standard of living of the population and requires significant changes.

The reasons for this are, first of all, lack of planning and control over the formation and use of profits of the enterprise, clear estimation of profitability indicators of previous and current periods and forecasting for the future. Therefore, there is a need to develop an effective one management of entrepreneurship in the economy, both at the country level and region.

In a market environment, in order to be successful in competition, business activity must quickly adapt to changing environmental factors, and focus its efforts on improving the product market offered to best meet customer needs. Achieving this goal is impossible without the involvement of a human factor, which is crucial for a business entity to succeed in competition. However, in order for human capital to provide entrepreneurship with the expected result, it is important to use effective innovative technologies to motivate employees $[3$, p. 65].

\section{The motivational mechanism of entrepreneurial activity in the system of providing entrepreneurship development in the modern economy}

Entrepreneurial activity in today's economy - a special function of economic entities, which is determined by the awarenessreasons for motives, which are due tomany factors. That is why further investigation of the motivational mechanism of entrepreneurial activity requires finding out the nature and content of such activity, as well as the conditions and factors of its development. 
The management of human resources and in general the personnel of enterprises has been and remains in any state the most pressing problem, which cannot be compared to any other, since it is the right solution to the problem of managing labor and labor behavior in many respects determines the progressive socio-economic development of enterprises and states. The motivation of the staff always happened, but depending on certain factors, the economic situation of the enterprise and the country as a whole, changed.

The lack of a scientifically sound system of planning, organization, motivation and control of the activity of the enterprise, as well as well-considered criteria of work of employees of its structural divisions led to the actual equalization in the bonus system. And the lack of highly qualified personnel capable of ensuring the proper organization and functioning of the enterprise under market conditions, nullifies virtually all attempts of development, and even more so the introduction of a highly effective system of target management, in which the system of motivation belongs. Further weakening of work motivation will inevitably lead to exacerbation of negative socio-economic processes in our country [5, p. 255].

Motivation is an attribute of human consciousness as a factor that activates or causes its termination. The concept broader than motivation is the passion for work, that is, the conviction of the employee in the expediency, content of his work.

Strong engagement of employees with the activities of the organization causes a reduction in staff turnover, but has no clear impact on improving the efficiency of work. Motivation is a factor of work efficiency, but too high motivation of the individual leads to numerous complications in its functioning. Therefore, the motivation process needs to be optimized. Hence, there is an objective need to create a science-based mechanism for motivating the work of enterprise personnel, which could, through effective levers and incentives, increase the interest of workers productively and qualitatively work, contribute to raising their competitiveness, to ensure a quality upgrade of the labor mentality. Also needed is a toolkit of a motivational mechanism capable of combining the goals and outputs of staff in a single node to put into practice the goal-oriented motivation of its highly productive work.

The mechanism of implementation of the tax policy is a system of plans, notices and regulations, organizational, administrative and social events, aimed at resolving the personal problems and satisfying the needs of the beneficiaries. 
The motive of human activity is to meet their needs, which have a complex hierarchical structure, different in different individuals. Each person directs his or her efforts towards the goals that meet his / her needs. Therefore, the most effective motivation is achieved when employees expect that, as best they can, in fulfilling their duties and contributing to the goals of the organization, they will receive sufficient compensation (material and moral) to meet their own needs. In other words, effective motivation requires a match between the goals of the employees and the organization. Of great importance for motivation is the employee's awareness of the fairness of the remuneration in comparison with the effort spent and the benefit brought to the organization, on the one hand, and the efforts brought by the benefit and reward of their colleagues, on the other.

Thus, optimization of the system of motivation of work of personnel can give: increase of productivity of work of employees; prompt achievement of company goals; the relationship of employee performance to pay and intangible incentives - that is, the relationship of effort to the result; transparency of the remuneration system; reducing staff turnover and overcoming staffing shortages; intensification of motivation to achieve significant results and strategic goals for the company; a balanced budget for material and non-material incentives; improving the psychological climate in the team; increase of employee loyalty; improving teamwork. In the process of motivation, one must take into account objective factors, that is, those that create independent preconditions for the subject's activity and subjective, which are associated with the ideal processing of external conditions in the mind and psyche of people. Objective factors are considered as the sphere of external stimuli to activity (stimuli), and subjective ones - as the basis of internal motives (motives) [6, p. 9].

Motivation includes tangible and intangible motives based on the purposeful formation of work motives and on the use of existing motives. In the process of motivation, many economic, organizational, legal, social and psychological, technological and other factors should be regulated in such a way that the activity of employees is carried out in the desired direction. With the right actions on the part of the management, it is possible to activate the personality, its intellectual, emotional and volitional spheres, to ensure the realization of potential intellectual-creative and psychophysiological capabilities of each worker. 
It should be noted that the form and indicators of incentives should be simple, understandable for all workers and they must be certain that their efforts and results of activities will not go unnoticed. In practice, the manager must use motives in a certain proportion, which was pointed out by Nobel Prize winner J. Galbraith. He noted that some motives reinforce each other, others combine weakly, and others mutually exclude, neutralize each other.

Motivation can be achieved through the exchange of experience and knowledge between leaders and subordinates, and frank expression of opinions at meetings, meetings, meetings and conferences. For this purpose, managers must create an atmosphere of openness and kindness, show constant interest in the initiatives of subordinates, always make reference to their business proposals.

Not only material and moral incentives, but also social sanctions against the person whose activity is at odds with certain norms of social environment (comments of colleagues, ridicule) play an important role in management. It is the desire to «justify the hopes of colleagues, their loved ones», to earn their approval becomes sometimes a strong internal motive, which helps a person to successfully fulfill the duties assigned to him, to overcome certain difficulties [7, p. 121].

There are some negative points that can be observed in the practice of motivation of workers in the industrial sphere of the Ukrainian economy: excessive enthusiasm for monetary (material) incentives, use of limited forms of incentives (money, gifts, certificates of honor, etc.), failure to observe certain psychological and ethical norms. etc. In other words, the principles of incentives acquired by science and proven by many years of practice are not fully respected: the complexity of incentives (material, creative, prestigious, the combination of incentives and sanctions), its publicity, involvement of all workers in solving incentive issues, differentiation of incentives with regard to employees' social needs and their attitude to incentives, timeliness and fairness of incentives, choice of effective remuneration procedures or imposition of penalties.

Negative motivation is sometimes caused by problems of a socio-psychological nature: relationships in the team, the psychological climate that has developed, and frequent conflict situations. Practice has convincingly 
shown that it is more efficient to eliminate antistimulates (negative motivations) than to overcome their harms with the help of positive motives. Management must use all forms of external influence on the employee's personality in order to perform the desired actions on his own motives than under the influence of formal instructions.

The complexity of the problem of motivation is not that it is difficult to sufficiently take into account the motivating motives of human activity, but that the structure of needs is not different in different people, and they change over time and in a certain situation.

The motivational mechanism should rely first and foremost on the existing system of material and intangible incentives. Material incentives include the following factors: basic remuneration: piecework (direct, piecework-bonus, chord), hourly, chord-bonus, chord-bonus with hourly advance, stimulation by the method of brigade (family) contract; additional payment for exceeding the plan of production and sale of products, payment for quality of works and products, payment for preservation of products; bonuses: on the final results of work, on the results of performance of self-supporting tasks, the most important types of works, high quality of works, introduction of achievements of science and excellence, for rationalization work and invention, saving of raw materials.

Intangible incentives, in turn, are based on the following factors: a gratitude announcement with the entry (without entry) on the honors board; awarding certificates of honor, valuable gifts; assignment of honorary titles; submission to government awards.

The spectrum of needs of the population of our country is quite wide and here it is impossible to be limited only by a certain amount of material goods, creation of some household conveniences, etc. At present, high hopes are placed on privatization as an additional source of labor activity. According to many scientists and practitioners, private property causes instinctive motivation and spiritual motives for hard work, it stimulates economic entrepreneurship and personal initiative [8, p. 326].

To solve these problems, it is necessary and appropriate to use effective motivation factors, including: organization of the production process (ensuring ergonomics, hygiene, environmental friendliness, aesthetic working conditions, clarity of working rhythm, etc.), system of stimulation of work (adherence to principles social justice, mutual assistance, compulsory 
compensation of material costs incurred by the employee due to negligence), individual measures of material and moral motivation for high-performance Noah's work (remuneration, promotion of professional rank, assignment of difficult and responsible tasks, business trip to study, abroad, etc.), personal example and business assignments.

An important element of the general moral and psychological state of a person is the factor of job satisfaction. Its value cannot be reduced only to the production effect, the degree of employee's return. It is found that job satisfaction creates a good mood, the necessary emotional background for optimism, even in difficult and stressful situations. At the same time, dissatisfaction with work over a long period of time causes a depressed state, pessimism, inertia. Elimination of various disruptions in work and the application of new, more sophisticated forms of work organization that act as motivators for high-performance work. In developed countries, new tools of motivation include "job enrichment", "complex optimization", flex-style, "decision-making" and so on.

This group of motivators may include: a) expanding the «vertical set» of duties, that is, ensuring greater autonomy and responsibility of the employee in the execution of the task, including in his duties some functions of planning and quality control of products; b) the extension of a "horizontal set" of responsibilities, that is, greater diversity in work within one function; c) production rotation of workers, ie change of professions in order to reduce the monotony of work; d) the creation of so-called «quality centers» that stimulate the initiative of workers in solving various production problems, etc. Nowadays, "quality centers" are a form of group labor organization that is developing most dynamically in many countries with a market economy. The effectiveness of this form of organization of work is based on a whole set of rather specific methods that constitute the Japanese model of intra-firm management $[9$, p. 92].

The diversity of views confirms that motivation is a complex process, the effectiveness of which is judged by the results of the enterprise. The main tasks of motivation: formation of each employee understanding of the essence and importance of motivation in the work process; training of staff and management staff in psychological basics of intercompany communication; formation of each leader of democratic approaches to personnel management using modern methods of motivation. 


\section{Improvement of the mechanism of state regulation of entrepreneurship motivation}

The urgency of the problem of motivation for Ukraine is determined by a number of socio-economic indicators reflecting the process of slowing down economic development and the negative socio-economic situation of the country:

- poor quality of life: $92.9 \%$ of all household expenditures are consumed, and over $49.6 \%$ of their total expenditure is on food;

- slowing down the development of small entrepreneurship: there are only 76 small enterprises per 10 thousand people; the average number of employees in them is 6 ; small enterprises produce only $18.2 \%$ of the volume of sales; $26.1 \%$ of small businesses are unprofitable;

- impossibility of forming accumulation and development funds at enterprises: capital investments at the expense of the state budget make up $2,4 \%$ of the total amount of invested funds; at the expense of local budgets $5.0 \%$; at the expense of own funds of enterprises $13-67,4 \%$; at the expense of loans and other loans $-7.3 \%$, at the expense of foreign investors $-3.1 \%$;

- high level of depreciation of fixed assets of production: $60.1 \%$ of fixed assets have exhausted themselves both morally and physically;

According to a United Nations expert's study of living standards of Ukrainians, about $80 \%$ of our country's citizens live below the poverty line. By UN standards: If a person spends less than $\$ 5$ a day on living and food and less than $\$ 150$ a month, he or she lives below the poverty line. According to the minimum wage indicators (since January 2017, the minimum wage in Ukraine is UAH 3,200, at the hryvnia exchange rate as of September 1, 2018 (UAH 27,1909 for \$ 1) is about \$ 118. a month), even a working Ukrainian a day can afford to spend no more than 107 UAH (\$4).

In order to ensure the sustainable development of the national economy, public authorities use coercive and stimulating tools to develop an enterprise system based on motivation for entrepreneurship. State policy instruments on entrepreneurship motivation can be presented as a mutually conditioned and interconnected system of five blocks: legal and information instruments; and financial instruments; strategic and national priorities; tools for the de-shadowing and legitimization of activities; development support.

The current national legislation, the development of entrepreneurship is recognized as a major factor, which should contribute to the creation of 
a positive socio-economic image of Ukraine, ensuring an efficient market economy with a view to its integration into the European and world economic systems. Creating a favorable business climate in Ukraine should be

the key to consolidating efforts to improve the level of cooperation with donor organizations and participation in international projects. Public policy is aimed at joiningUkraine to international programs, signing bilateral and multilateral interstate and interagency agreements to support small business. Currently, in most national entrepreneurship development programs, the focus is primarily on small business development. But, as noted earlier, the existing concept of entrepreneurship does not cover the sector of large enterprises of the national economy [10, p. 98].

However, adequate motivation for business development must take into account the establishment of strong relationships between all types of business in the national economy. That is, to cover the whole enterprise system.

This is due to the fact that the achievement of strategic goals and successful implementation of national socio-economic programs is possible only if the financial and material resources of corporate business are utilized using potential and medium-sized entrepreneurship as more variable and able to better adapt to the fast-moving needs of the market. This interconnection system has been used successfully in the Japanese business development model: effective communications help reduce inventory, streamline justintime deliveries, and increase the competitiveness of business entities by improving logistics. Therefore, the effectiveness of communication between business entities is partly dependent on saving working capital and increasing their turnover rate. But the formation of such a system of interconnections requires state support for the stabilization and harmonization of the business environment [11, p. 169].

Effective support for entrepreneurs' motivation to implement activity in the state is possible on the basis of the formation of economically justified preconditions and rules of entrepreneurial activity. The whole set of elements of such infrastructure can be divided into five key areas: organizational and technical; resource; financial and An important problem of entrepreneurship is the provision of their financial resources. Despite the increase in the number of small and medium-sized enterprises, a significant proportion of them operate at a loss, the activities of most small businesses are increasingly financed by borrowing capital. causes the banks to strictly 
require the repayment of loans and the high interest rate on them, which in turn leads to the restriction of access of small businesses to borrowing capital. A problematic aspect of small businesses' economic relationships with banks is the short lending period, since long-term loans to small businesses are in most cases incapable of securing collateral. New start-ups or business projects cannot receive credits because of the manager's lack of business experience. Leading banks refuse to provide them with a loan because it is important for the bank to work with reliable borrowers with established businesses.

Therefore, the financial and credit policy of the state should be aimed at creating favorable conditions for starting and implementation of entrepreneurial activity, availability of financial resources for enterprises - business entities, because the limited financial resources becomes a factor in the development of small and medium-sized businesses.

Important is the introduction of effective mechanisms to stimulate innovation and investment activities of domestic businesses. The main forms of state support for the development of small and medium-sized businesses can be: partial compensation for factoring and leasing payments; partial compensation of interest rates on loans aimed at the implementation of innovative projects of small and medium-sized enterprises; compensation for the development costs of cooperation between small and medium-sized enterprises and large enterprises; support for the implementation of clean and energy-saving technologies; providing guarantees on the loans of small and medium enterprises; providing loans for starting and running your own business. First of all, it is advisable to support innovative entrepreneurship. In this case, the world practice of state regulation of entrepreneurship makes extensive use of targeted investments related to the financing of know-how, the introduction of high technology and information technology [12, p. 57].

In general, the system of financial support and incentives for business entities should be based on compliance with the principles of legal protection, stability and their economic interest. Therefore, improvement requires a regulatory framework on the motivation mechanism and regulation of entrepreneurship development.

The measures aimed at ensuring the sustainable development of the country should include: the focus of state support for improving the living conditions and standard of living of the population; diversification of the 
structure of domestic production; ensuring the parity of prices for products of industry and agriculture; support for the development of depressed territories, provision of adequate information support to the subject of entrepreneurship; application of an effective system of crediting andinsurance of export operations; recognition of the priority of providing state export support to business entities that use energy and resource-saving innovative technologies in their activities.

The mechanism of state motivation for the development of the enterprise should cover all areas of business. In order to increase the competitiveness of the subjects of the domestic business environment, it is necessary to synthesize the existing business support tools with the tools of infrastructure development and the system of interconnections between the entities. The mechanism of state support for the development of entrepreneurial activity in the direction of achieving strategic goals and implementation of socio-economic national programs at the state and regional level should use the available resources of large, medium and small businesses, depending on the possible return of these resources to maximize the benefits of subjects of the national business environment internally and externally markets.

\section{Conclusions}

Motivational aspects are becoming increasingly important in entrepreneurship, since the commercial success of any enterprise depends first and foremost on the extent to which employees realize their professional potential. Despite the fact that there are many motivational theories and motivation schemes, for most executives of different organizations the problem of efficiency and formation of effective motivational mechanism of personnel in the process of strategic enterprise management always arises.

Specification of the main elements of the motivational mechanism and regulatory support for the motivational mechanism for the development of entrepreneurial activity in the modern national economy is based on the proposed logical and meaningful scheme, which combines: target orientations for the development of entrepreneurship, principles of construction and operation of the motivational mechanism of entrepreneurial activity, general economic directions of state regulation of pi motivation entrepreneurship that is consistent with the main directions of state economic and 
regulatory policy. This allows to determine the system of measuresstate regulation of the development of business sectornational economy.

It is substantiated that the conceptual basis of economic and regulatory policy of the state to motivate entrepreneurial activity in the modern economy of Ukraine should be based on the reorientation of the principles of state policy in the field of entrepreneurship to support and compel to stimulate and stimulate entrepreneurial activity. It is proved that: measurespolicies should cover entrepreneurship systematically and facilitate the establishment of relationships between all types of businessnational economy; the application of methods, instruments and instruments of public policy should be differentiated andspecified depending on the type and size of business (enterprises), industry and type of activity, phases of the economic cycle in general and the development of entrepreneurship in particular. This will ensure the effectiveness of public policy for the development of entrepreneurship.

\section{References:}

1. Smith A. (1962). Issledovanie o prirode i prichinakh bogatstva narodov [A Study of the Nature and Causes of the Wealth of Nations]. Moscow: Aspect Press. (in Russian)

2. Ofitsiinyi sait Derzhavnoho komitetu statystyky Ukrainy [Official site of the State Statistics Committee of Ukraine]. Retrieved from: http://www.ukrstat.gov.ua (accessed 18 October2019).

3. Ofitsiinyi sait proektu Doing business [Official website of the Doing business project]. Retrieved from: http://www.doingbusiness.org/ru/reports/global-reports/doing-business-2019 (accessed 10 October2019).

4. Marshall A (1920). Principles of Economic Science. Book. 1. London: Macmillan and Co. 8th ed.

5. Schumpeter J. (1982). Teoriya ekonomicheskogo svyazi [The theory of economic connection]. Moscow: Progress. (in Russian)

6. Malik M.I., Shpikuliak A.G. (2006). Rozvytok pidpryjemnyctva v aghrarnomu sektori ekonomiky [Development of entrepreneurship in the agrarian sector of the economy]. Ekonomika APK [AIC economy], vol 4, pp. 3-10. (in Ukrainian)

7. Bilichenko O.S. (2012). Klasychni i suchasni modeli motyvatsii trudovoi diialnosti [Classical and modern models of motivation work]. Visnyk ahrarnoyi nauky Prychornomoria - Journal of agricultural science of Black Sea [Bulletin of agrarian science. The Black Sea], vol. 4, pp. 119-125. (in Ukrainian)

8. Derenko O.M. (2019). Teoretychni aspekty motyvaciji praci v siljsjkoghospodarsjkomu vyrobnyctvi [Theoretical aspects of labor motivation in agricultural production]. Zbirnyk naukovykh pracj Podiljsjkogho derzhavnogho aghrarno tekhnichnogho universytetu [Collection of scientific works of Podilsky State Agrarian and Technical University], vol. 16, no. 3, pp. 324-326. (in Ukrainian) 
9. Grebinska S.I. (2018). Rozrobka system motyvaciji i oplaty praci na osnovi vykorystannja zarubizhnogho dosvidu [Development of motivation and payment systems on the basis of foreign business]. Visnyk Khmeljnycjkogho nacionaljnogho universytetu [News of the Khmelnitsky National University], vol. 5, no. 136, pp. 91-94. (in Ukrainian)

10. Ponomaryova M.S., Krivosheya E.V. (2019). Osoblyvosti funkcionuvannja ta rozvytok pidpryjemnyctva $\mathrm{v}$ umovakh integhracijnykh zrushenj [Features of functioning and development of entrepreneurship in terms of integration shifts]. Biznes-navighator [Business Navigator], vol. 1, no. 50, pp. 97-101. (in Ukrainian)

11. Shavshin O.S. (2017). Strateghija innovacijnogho rozvytku pidpryjemstva [Strategy of innovative development of the enterprise]. Ynternauka [Internship], vol. 3 , no. 25, pp. 167-171. (in Ukrainian)

12. Dyadin A.S. (2018). Definicija kateghoriji «pidpryjemnycjka dijaljnistj» [Definition of the category "entrepreneurial activity"]. Visnyk Chernighivsjkogho derzhavnogho tekhnologhichnogho universytetu. Serija Ekonomika [Bulletin of Chernihiv State Technological University. Economy series], vol. 1, no. 64, pp. 54-58. (in Ukrainian)

13. Keynes J.M. (1993). Obshchaya teoriya zanyatosti, protsenta i deneg. Antologiya ekonomicheskoy klassiki [The general theory of employment, interest and money. Anthology of economic classics]. Moscow: Ekonov-Klyuch. (in Russian)

14. Revyakin O.O. (2018). Ekonomiko-orghanizacijni aspekty motyvaciji personalu $\mathrm{v}$ procesi detinizaciji pidpryjem nycjkoji dijaljnost [Economic and organizational aspects of personnel motivation in the process of shadowing entrepreneurial activity]. Formuvannja rynkovykh vidnosyn v Ukrajini [Formation of market relations in Ukraine], vol. 2, no. 141, pp. 202-206. (in Ukrainian)

15. Ulianchenko O.V., Sheludko R.M., Ponomarova M.S., Sheludko L.V. (2019). Motivation management as the key factor of financial and economic growth of small agribusiness enterprises. Financial and credit activity: problems of theory and practice, vol. 4, no 31, pp. 239-248. (in Ukrainian) 